Part of Journal of Research of the National Bureau of Standards, Volume 20, June 1938

\title{
THERMAL EXPANSION AND EFFECTS OF HEAT TREAT. MENTS ON THE GROWTH, DENSITY, AND STRUCTURE OF SOME HEAT-RESISTING ALLOYS
}

\author{
By Peter Hidnert
}

\section{ABSTRACT}

Coefficients of linear expansion for various temperature ranges between 20 and $1,000^{\circ} \mathrm{C}$ were obtained on some new heat-resisting alloys: An iron-chromiumaluminum alloy and three iron-chromium-aluminum-cobalt alloys. No polymorphic transition was observed in these alloys between 20 and $1,000^{\circ} \mathrm{C}$. The alloys exhibited growth ( 0.82 to 2.81 percent) after various heat treatments at temperatures up to $1,400^{\circ} \mathrm{C}$. Additional heat treatments would probably cause additional growth. The densities of the mechanically worked iron-chromiumaluminum alloy and iron-chromium-aluminum-cobalt alloys increased 1.12 to 2.50 percent as a result of various heat treatments to $1,400^{\circ} \mathrm{C}$. Tremendous grain growth occurred in the heat-resisting alloys as a result of various heat treatments at elevated temperatures.

\section{CONTENTS}

I. Introduction

II. Materials investigated _.

III. Thermal-expansion apparatus _ _

IV. Thermal expansion of heat-resisting alloys

1. Iron-chromium-aluminum alloy _ _

2. Iron-chromium-aluminum-cobalt alloys

V. Effects of heat treatments on heat-resisting alloys

1. Growth

2. Density

3. Structure

VI. Discussion

VII. Conclusions

VIII. References

\section{INTRODUCTION}

The commercial alloys used for electric heating are primarily nickel-chromium and nickel-chromium-iron alloys. Recently, however, a new series of heat-resisting alloys composed primarily of iron and chromium with smaller additions of aluminum or aluminum and cobalt, has been developed. These alloys can be heated to higher temperatures than the nickel-chromium and iron-nickel-chromium alloys, but they have disadvantages which will be indicated later.

In 1931, data [1] ${ }^{1}$ on the linear thermal expansion of nickel-chromium, iron-chromium, and nickel-chromium-iron alloys were published. The present paper gives the results obtained in an investigation on the thermal expansion of the new heat-resisting alloys: Iron-chromiumaluminum alloy and iron-chromium-aluminum-cobalt alloys. Samples

1 The numbers in brackets here and elsewhere in the text refer to the references at the end of this paper. 
of these alloys were secured through the cooperation of two companies. ${ }^{2}$

Measurements were made of the linear thermal expansion of the alloys at various temperatures between 20 and $1,000^{\circ} \mathrm{C}$. The effects of various heat treatments between 1,000 and $1,400^{\circ} \mathrm{C}$ on the growth, density, and structure of these alloys, were also investigated. It is expected that these data will be useful to engineers, metallurgists, physicists, and others in the applications of these alloys; for example, in the design of equipment for high-temperature processes.

\section{MATERIALS INVESTIGATED}

Four samples of heat-resisting alloys (iron-chromium-aluminum and iron-chromium-aluminum-cobalt) were investigated. Table 1 gives the trade names, chemical compositions, heat treatments, etc.

\footnotetext{
${ }^{2}$ The author expresses his appreciation for the cooperation by C. O. Jelliff Mfg. Corporation, Southport, Conn., and Hoskins Mfg. Co., Detroit, Mich. These companies furnished the samples of heat-resisting alloys and information about their preparation.
} 
TABLE 1.-Chemical composition and heat treatment of heat-resisting alloys

\begin{tabular}{l|l|l|l|l|l|l|l|l|l|}
\hline \multirow{3}{*}{ Sample } & \multicolumn{4}{|c|}{ Chemical composition a } & $\begin{array}{c}\text { Heat treat- } \\
\text { ment }\end{array}$ & $\begin{array}{c}\text { Cross-section of } \\
\text { sample }\end{array}$ & Mamufacturer \\
\cline { 3 - 4 } & $\mathrm{Cr}$ & $\mathrm{Al}$ & $\mathrm{Co}$ & $\mathrm{Fe}$ & $\mathrm{Mn}$ & $\mathrm{Si}$ & $\mathrm{C}$ & Remarks by manufacturer \\
\hline
\end{tabular}

(a) IRON-CHROMIUM-ALUMINUM ALLOYS

\begin{tabular}{|c|c|c|c|c|c|c|c|c|c|c|c|c|}
\hline $1586 \ldots$ & $\begin{array}{l}\text { Hoskins' Alloy } \\
\text { No. 10.0 }\end{array}$ & $\begin{array}{l}\text { Per- } \\
\text { cent } \\
38.6\end{array}$ & $\begin{array}{l}\text { Per- } \\
\text { cent } \\
7.9\end{array}$ & $\begin{array}{l}\text { Per- } \\
\text { cent }\end{array}$ & $\begin{array}{l}\text { Per- } \\
\text { cent } \\
53.1\end{array}$ & $\begin{array}{l}\text { Per- } \\
\text { cent } \\
0.17\end{array}$ & $\begin{array}{l}\text { Per- } \\
\text { cent } \\
0.19\end{array}$ & $\begin{array}{l}\text { Per- } \\
\text { cent } \\
0.05\end{array}$ & Hot-rolled... & 1/4-in. diam.. & Hoskins Mfg. Co. & $\begin{array}{l}\text { Hoyt and Archer [2] stated that an object of of } \\
\text { their invention was to provide an alloy of } \\
\text { such properties as to be suitable for the fabri- } \\
\text { cation of cast or wrought articles which are } \\
\text { exposed to oxidizing conditions at elevated } \\
\text { temperatures, such as annealing or carburizing } \\
\text { boxes, or parts entering into the construction } \\
\text { of conveyors, heat exchangers, recuperators, } \\
\text { or other mechanism exposed to the action of } \\
\text { oxidizing atmospheres at elevated tempera- } \\
\text { tures. Another object was to provide an } \\
\text { alloy suitable for the construction. of electrical } \\
\text { resistance elements capable of operating at } \\
\text { high temperature with a long life. }\end{array}$ \\
\hline
\end{tabular}

(b) IRON-CHROMIUM-ALUMINUM-COBALT ALLOYS d

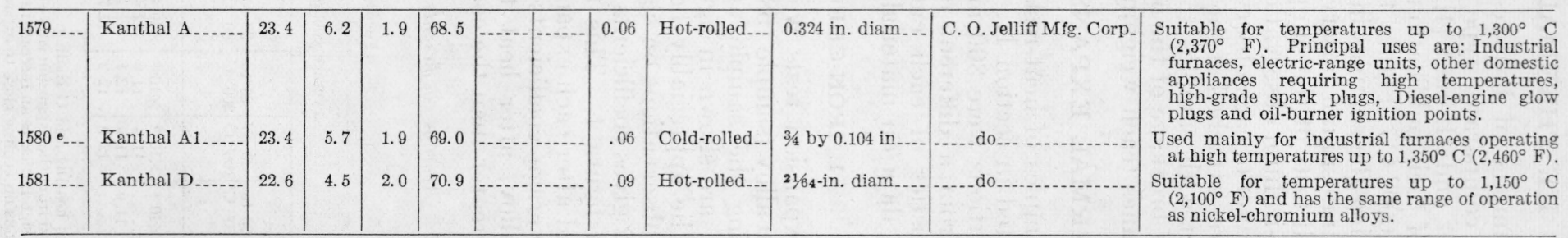

a Chemical analyses were made on pieces cut from both ends of each sample after the thermal-expansion determinations had been completed.

- Pame as Smith Alloy No. 10 (see Hoyt and Scheil [5]).

d Kantzow [3], the inventor of Kanthal alloys, stated that "his invention makes it possible to obtain alloys having, in most eases, better properties than those of the Nichrome,

at a considerably lower price than that of the latter." 


\section{THERMAL-EXPANSION APPARATUS}

The samples of heat-resisting alloys were investigated with the precision comparator type of thermal-expansion apparatus described by Souder and Hidnert [4]. The white furnace shown at the left of figure 1 of their publication was used for temperature ranges between 20 and $1,000^{\circ} \mathrm{C}$. Figure 4 of the same publication shows the details of mounting the samples in the furnace.

Platinum-osmium observation wires (6 $\frac{1}{2}$ percent of osmium) were used in all tests of the samples except sample 1579. For this sample, platinum-iridium observation wires (20 percent of iridium) were used. The diameter of each observation wire was $0.050 \mathrm{~mm}$. A vane weighing $18 \mathrm{~g}$ was attached at the bottom of each observation wire which was in contact with samples 1579 and 1581 . In order to reduce the possibility of breakage of the observation wires at elevated temperatures, lighter vanes (each weighing $9 \mathrm{~g}$ ) were used with the other samples.

\section{THERMAL EXPANSION OF HEAT-RESISTING ALLOYS}

The samples of heat-resisting alloys were arranged in two groups, as indicated in section II. The samples used for thermal-expansion determinations were $300 \mathrm{~mm}$ in length. Each expansion curve was plotted from a different origin in order to display the individual characteristics of each curve. Results obtained in a second test represent data on material after the heat treatment incident to the first test.

\section{IRON-CHROMIUM-ALUMINUM ALLOY}

Two expansion tests were made on a hot-rolled iron-chromiumaluminum alloy (sample 1586). The observations obtained on heating and cooling the sample at various temperatures between 20 and $1,000^{\circ} \mathrm{C}$. are shown in figure 1 . The observations on cooling in the first test lie appreciably below the expansion curve. In the second test, the observations on cooling are very close to the expansion curve.

Table 2 gives coefficients of expansion which were derived from the curves in figure 1 . This table also shows the difference in length before and after each expansion test.

The average coefficients of expansion of the iron-chromium-aluminum alloy, after heat treatment incident to the first test, are slightly greater than the coefficients of the hot-rolled alloy.

TABLE 2.-Average coefficients of linear expansion of hot-rolled iron-chromiumaluminum alloy

[Fe 53.1, Cr 38.6, Al 7.9, percent]

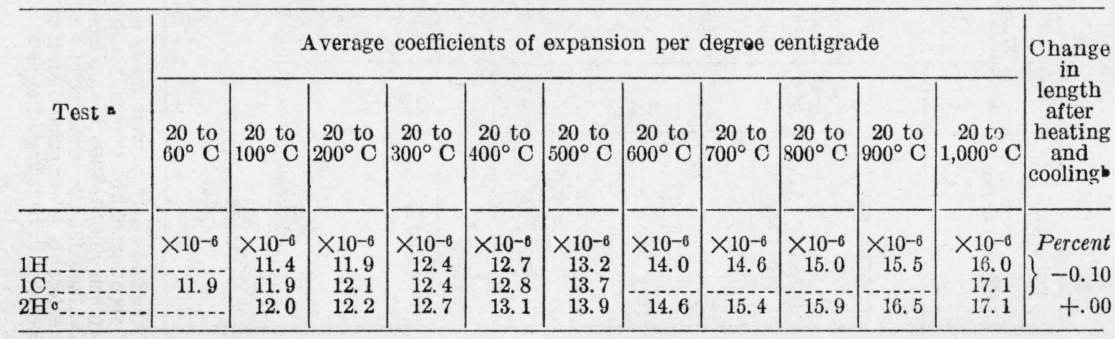

a $\mathrm{H}$ indicates heating and $\mathrm{C}$ cooling.

- Determined from the expansion curve on heating and the contraction curve (or observation) on cooling. The plus $(+)$ sign indicates an increase in length and the minus ( $)$ sign a decrease in length.

- Observations on cooling close to expansion curve on heating. 
In 1935, Hoyt and Scheil [5] reported that the coefficient of linear expansion of Smith Alloy No. $10^{3}$ is about $18 \times 10^{-6}$ per degree C between room temperature and $1,315^{\circ} \mathrm{C}$. "This means an expansion of about 0.27 inch per foot, on heating to 2,400 degrees Fahr. (1,315 degrees Cent.). These determinations were made on wire in the life

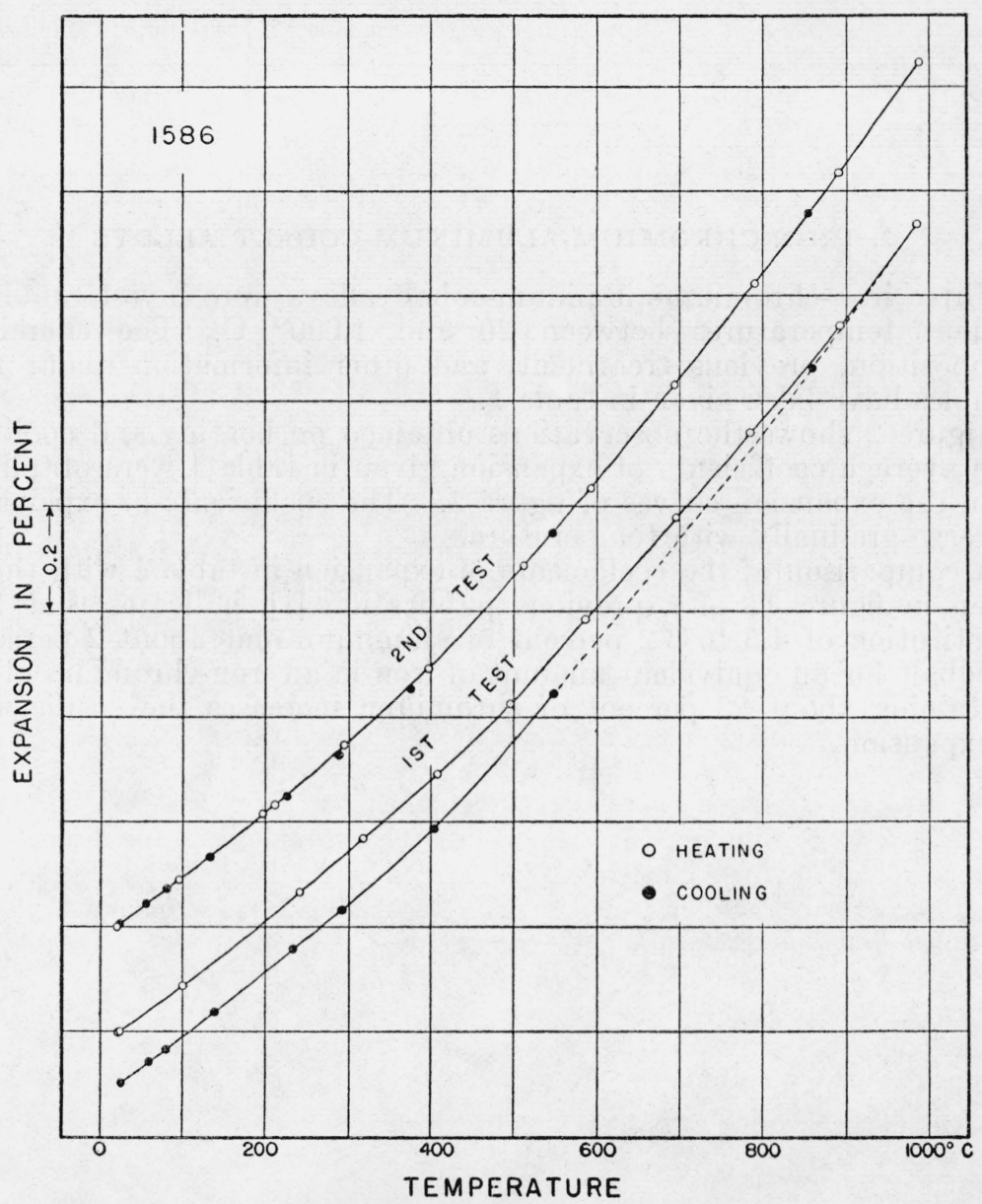

FIGURE 1.-Linear thermal expansion of hot-rolled iron-chromium-aluminum alloy. $\mathrm{Fe} 53.1$, Cr 38.6, Al 7.9, Mn 0.17, Si 0.19, C 0.05 percent.

tester with the Ames dial and are subject to a minor correction when more accurate determinations become available."

Table 3 gives coefficients of expansion of two iron-aluminum alloys investigated by Schulze [6]. From interpolation and comparison of these coefficients of expansion with those given in table 2, it appears that the substitution of approximately 39 percent of chromium for the same amount of iron in an iron-aluminum alloy containing about 8 percent of aluminum, has little effect on the coefficients of expansion for temperature ranges between 20 and $500^{\circ} \mathrm{C}$.

${ }^{3}$ Same as Hoskins' Alloy No. 10 (see table 1). 
TABLE 3.-Coefficients of expansion of annealed iron-aluminum alloys [Schulze, reference 6]

\begin{tabular}{c|r|r|r}
\hline Aluminum content & \multicolumn{3}{|c}{$\begin{array}{r}\text { Average coefficients of linear expansion } \\
\text { per degree centigrade }\end{array}$} \\
\cline { 2 - 4 } & 20 to $100^{\circ} \mathrm{C}$ & 20 to $300^{\circ} \mathrm{C}$ & 20 to $500^{\circ} \mathrm{C}$ \\
\hline Percent & $\times 10^{-6}$ & $\times 10^{-6}$ & $\times 10^{-6}$ \\
12.0 & 13.0 & 13.8 \\
10.56 & 12.2 & 13.3 & 14.0 \\
\hline
\end{tabular}

\section{IRON-CHROMIUM-ALUMINUM-COBALT ALLOYS}

Three iron-chromium-aluminum-cobalt alloys were investigated at various temperatures between 20 and $1,000^{\circ} \mathrm{C}$. The chemical composition, previous treatment, and other information about the samples have been given in table 1 .

Figure 2 shows the observations obtained on heating and cooling. The average coefficients of expansion given in table 4 were obtained from the expansion curves of figure 2. The coefficients of expansion increase gradually with temperature.

A comparison of the coefficients of expansion in table 4 with those given in figure 11 of a previous publication [1], indicates that the substitution of 4.5 to 6.2 percent of aluminum and about 2 percent of cobalt for an equivalent amount of iron in an iron-chromium alloy containing about 23 percent of chromium, increases the coefficients of expansion. 


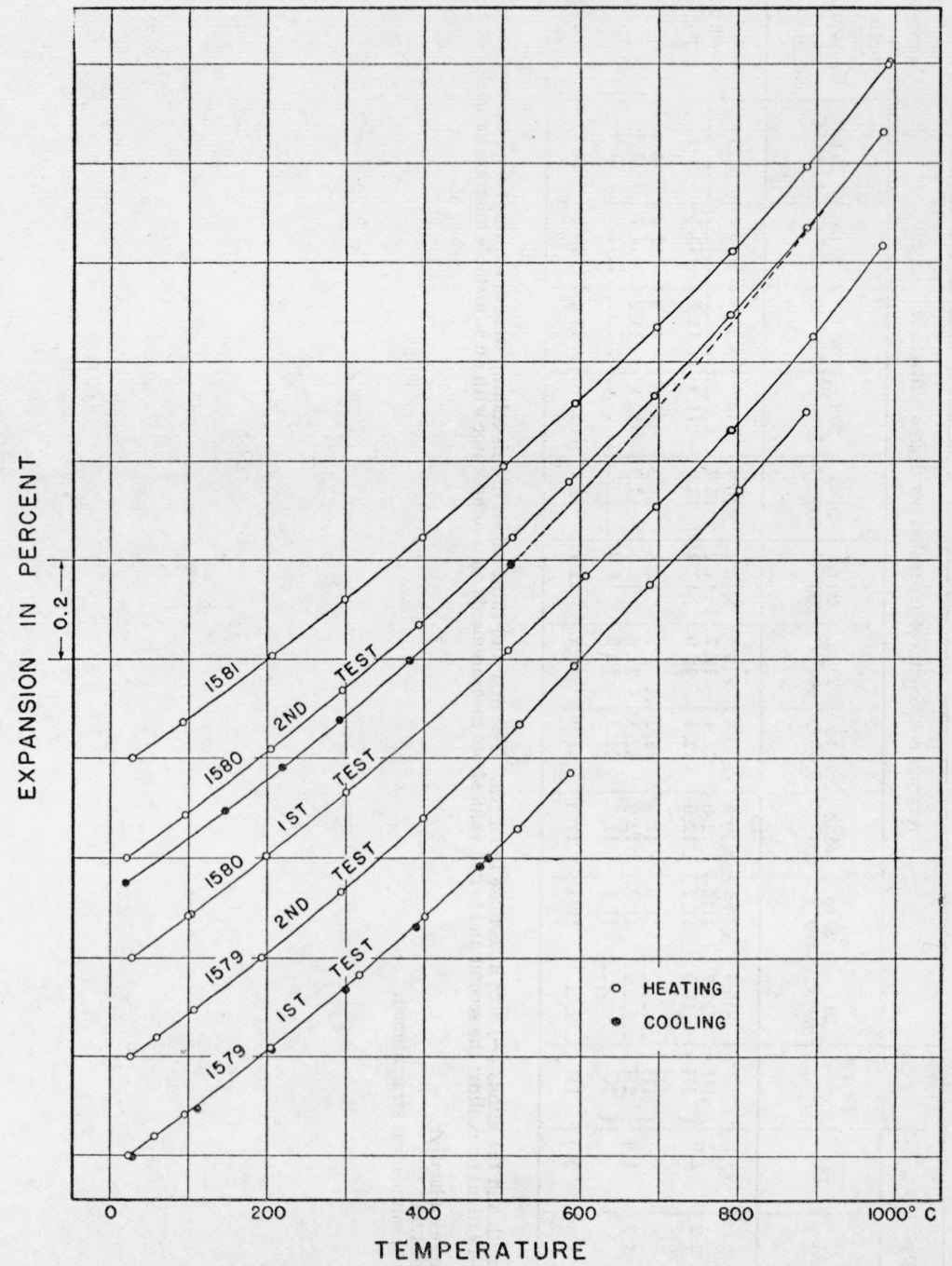

Figure 2.-Linear thermal expansion of three iron-chromium-aluminum-cobalt alloys.

Sample 1579, Fe 68.5, Cr 23.4, Al 6.2, Co 1.9, C 0.06 percent (hot-rolled).

Sample 1580, Fe 69.0, Cr 23.4, Al 5.7, Co 1.9, C 0.06 percent (cold-rolled).

Sample 1581, Fe 70.9, Cr 22.6, Al 4.5, Co 2.0. C 0.09 percent (hot-rolled). 
TABLE 4.-Average coefficients of linear expansion of iron-chromium-aluminum-cobalt alloys

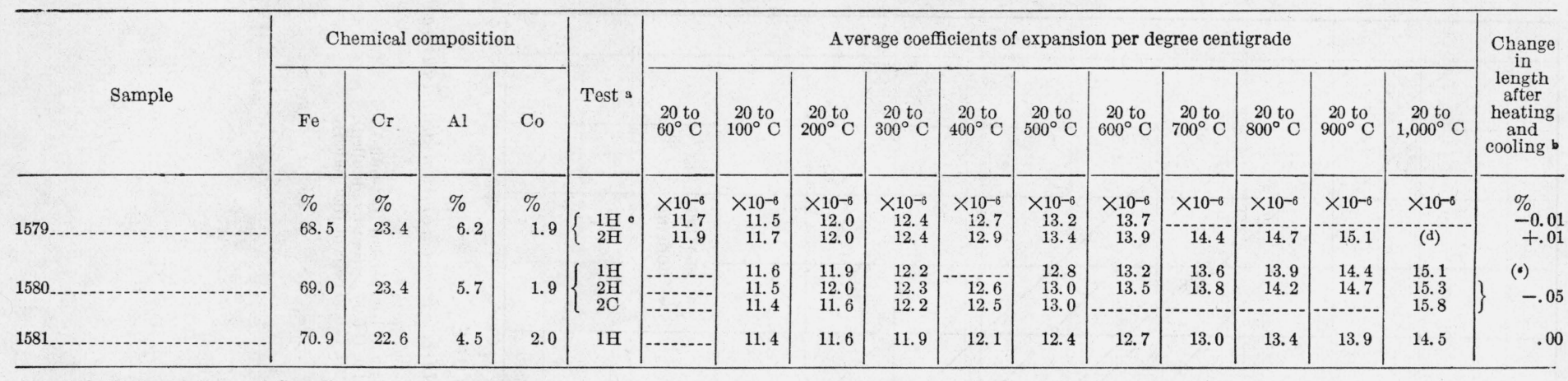

a $\mathrm{H}$ indicates heating and $\mathrm{C}$ cooling.

b The plus ( + ) sign indicates an increase in length and the minus $(-)$ sign a decrease in length. The first and third values in this column were determined from the expansion curve on heating and the contraction curve (or observation) on cooling; the second and fourth values from measurements on a comparator with an adjustable micrometer head, set to an end standard of known length.

- Observations on cooling close to expansion curve on heating.

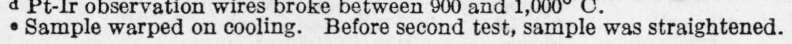




\section{EFFECTS OF HEAT TREATMENTS ON HEAT-RESISTING ALLOYS}

The results obtained on the effects of heat treatments on the growth, density, and structure of the samples of heat-resisting alloys are given in the following subsections.

\section{GROWTH}

After the thermal-expansion determinations were completed on the samples of heat-resisting alloys, $50-\mathrm{mm}$ pieces were cut from both ends of each sample for chemical analyses. ${ }^{4}$ Density determinations were made on the remaining pieces of the samples. These pieces (each $200 \mathrm{~mm}$ long) were then heated ${ }^{5}$ to various temperatures between 1,100 and $1,400^{\circ} \mathrm{C}$, held at these temperatures for various lengths of time and then cooled to room temperature. Measurements were made on the grow th (or shrinkage) of these samples after each heat treatment. Table 5 shows the results obtained on these samples and on samples of Chromel A (sample 1292A) and Nichrome IV (sample 1293). Each value represents the growth (or shrinkage) from the original length before the first heat treatment. For each heat treatment, one-half of the difference between the value for the sample with oxide on the ends and the value for the sample with the oxide removed from the ends, represen ts the thickness of the oxide or scale on each end of the sample.

TABLE 5.-Growth of heat-resisting alloys

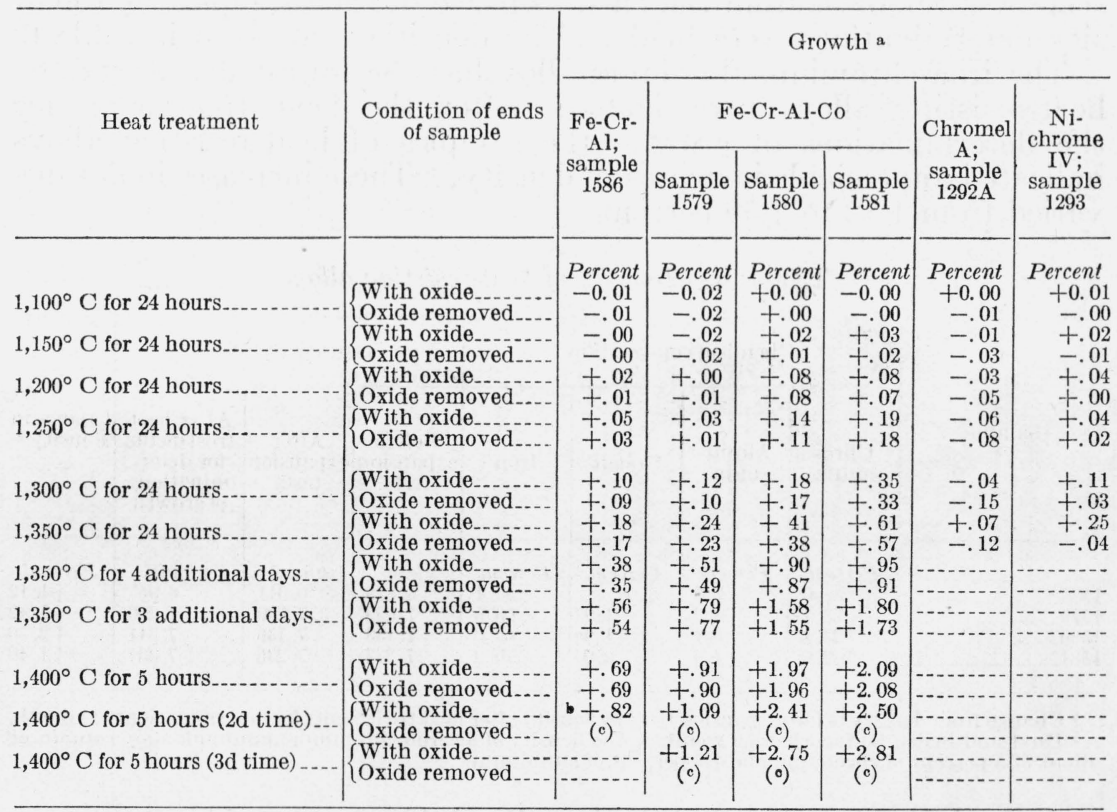

a Each value represents the growth (or shrinkage) from the original length before the first heat treatment. b Sample warped during heat treatment and was broken in attempting to straighten it.

- Slight oxide not removed.

4 Table 1 gives results of chemical analyses.

${ }^{5} \mathrm{~A}$ platinum-wound tube furnace was used for temperatures between 1,100 and $1,350^{\circ} \mathrm{C}$, in which the samples were exposed to air. A gas furnace was used for heating the samples to $1,400^{\circ} \mathrm{C}$.

$$
65622-38-7
$$


The samples of iron-chromium-aluminum-cobalt alloys indicated the greatest growth. The total growth after the various heat treatments ranged from 1.21 to 2.81 percent. The total growth of the sample of iron-chromium-aluminum alloy was nearly 1 percent. Additional heat treatments would probably cause additional growth of these alloys. A comparison of the growth and the aluminum content of these alloys indicates that the growth decreases with an increase in the aluminum content.

The samples of Chromel A and Nichrome IV scaled at elevated temperatures.

Hoyt and Scheil [5] found that wires of Smith Alloy No. $10^{6}$ grow when heated to high temperatures. They recommended that an allowance for growth of at least $1 / 4$ inch per foot be made, in addition to that for the expansion. This minimum allowance for growth corresponds to 2.1 percent.

\section{DENSITY}

Density determinations were made on the $300-\mathrm{mm}$ samples of heatresisting alloys before the thermal-expansion tests were undertaken. After the thermal-expansion tests were completed, $50-\mathrm{mm}$ pieces were cut from both ends of each sample for chemical analyses, and density determinations were made on the remajning pieces of the samples, as stated in the preceding subsection. After various heat treatments on these pieces for determinations of growth, oxide or scale was removed from the entire surface of each sample, ${ }^{7}$ and density determinations were made. The densities are given in table 6 .

The iron-chromium-aluminum alloy has the lowest density of the heat-resisting alloys investigated. After the heat treatments for the determinations of growth, the samples of heat-resisting alloys indicated appreciable increases in density. These increases in density varied from 1.12 to 2.50 percent.

TABLE 6.-Density of heat-resisting alloys

\begin{tabular}{|c|c|c|c|c|c|c|c|c|}
\hline \multirow[b]{2}{*}{ Sample } & \multicolumn{4}{|c|}{ Chemical composition } & \multicolumn{3}{|c|}{ Density at $23^{\circ} \mathrm{C}$} & \multirow[b]{2}{*}{$\begin{array}{l}\text { Change in } \\
\text { density }\end{array}$} \\
\hline & $\begin{array}{l}\text { Chro- } \\
\text { mium }\end{array}$ & $\underset{\text { numi- }}{\text { Alumi- }}$ & Cobalt & Iron & $\begin{array}{c}\text { Before } \\
\text { expansion } \\
\text { tests }\end{array}$ & $\begin{array}{c}\text { After } \\
\text { expansion } \\
\text { tests }\end{array}$ & $\begin{array}{l}\text { After heat } \\
\text { treatments } \\
\text { for deter- } \\
\text { minations } \\
\text { of growth }\end{array}$ & \\
\hline 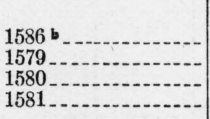 & $\begin{array}{r}\text { Percent } \\
38.6 \\
23.4 \\
23.4 \\
22.6\end{array}$ & $\begin{array}{r}\text { Percent } \\
7.9 \\
6.2 \\
5.7 \\
4.5\end{array}$ & $\begin{array}{r}\text { Percent } \\
1.9 \\
1.9 \\
2.0\end{array}$ & $\begin{array}{r}\text { Percent } \\
53.1 \\
68.5 \\
69.0 \\
70.9\end{array}$ & $\begin{array}{c}\mathrm{g} / \mathrm{cm}^{3} \\
6.878 \\
7.099 \\
7.133 \\
7.233\end{array}$ & $\begin{array}{c}\mathrm{g} / \mathrm{cm}^{3} \\
6.911 \\
7.099 \\
7.136 \\
7.235\end{array}$ & $\begin{array}{r}\mathrm{g} / \mathrm{cm}^{3} \\
6.955 \\
7.200 \\
7.311 \\
7.334\end{array}$ & $\begin{array}{l}\text { Percent } \\
\quad+1.12 \\
+1.42 \\
+2.50 \\
+1.40\end{array}$ \\
\hline
\end{tabular}

a Change from density before expansion tests to density after heat treatments for determinations of growth. b Hoyt and Scheil [5] reported $6.9 \mathrm{~g} / \mathrm{cm}^{3}$ for the density of an iron-chromium-aluminum alloy containing about 37.5 percent of chromium and 7.5 percent of aluminum.

As both the densities and the lengths of the samples of heat-resisting alloys increased, the cross-sectional areas of the samples must have decreased as a result of heat treatments to various temperatures up to $1,400^{\circ} \mathrm{C}$.

\footnotetext{
' Same as Hoskins' Alloy No. 10 (see table 1).

7 A small piece was cut from one end of each sample for examination of its structure.
} 




FIGURE 3.-Microstructure of iron-chromium-aluminum alloy (iron 53.1, chromium 38.6, aluminum 7.9, manganese 0.17 , silicon 0.19, carbon 0.05 percent); $\times 100$.

A. Sample 1586 (hot-rolled), before heat treatments. B. Sample 1586, after heat treatments to various temperatures up to $1,400^{\circ} \mathrm{C}$. 


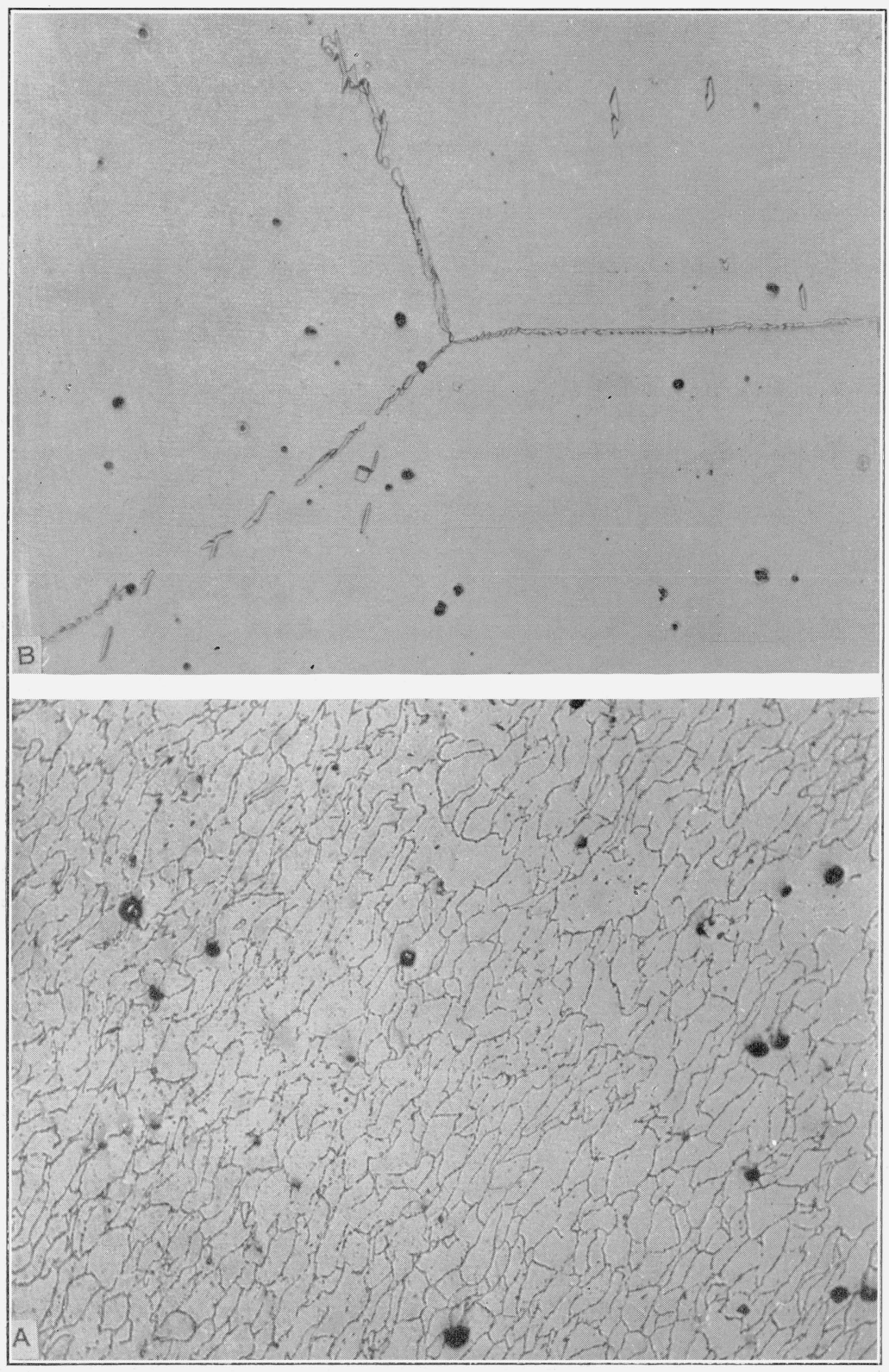

Figure 4.-Microstructure of iron-chromium-aluminum-cobalt alloy (iron 68.5, chromium 23.4, aluminum 6.2, cobalt 1.9, carbon 0.06 percent); $\times 100$.

A. Sample 1579 (hot-rolled), before heat treatments. B. Sample 1579, after heat treatments to various temperatures up to $1,400^{\circ} \mathrm{C}$. 


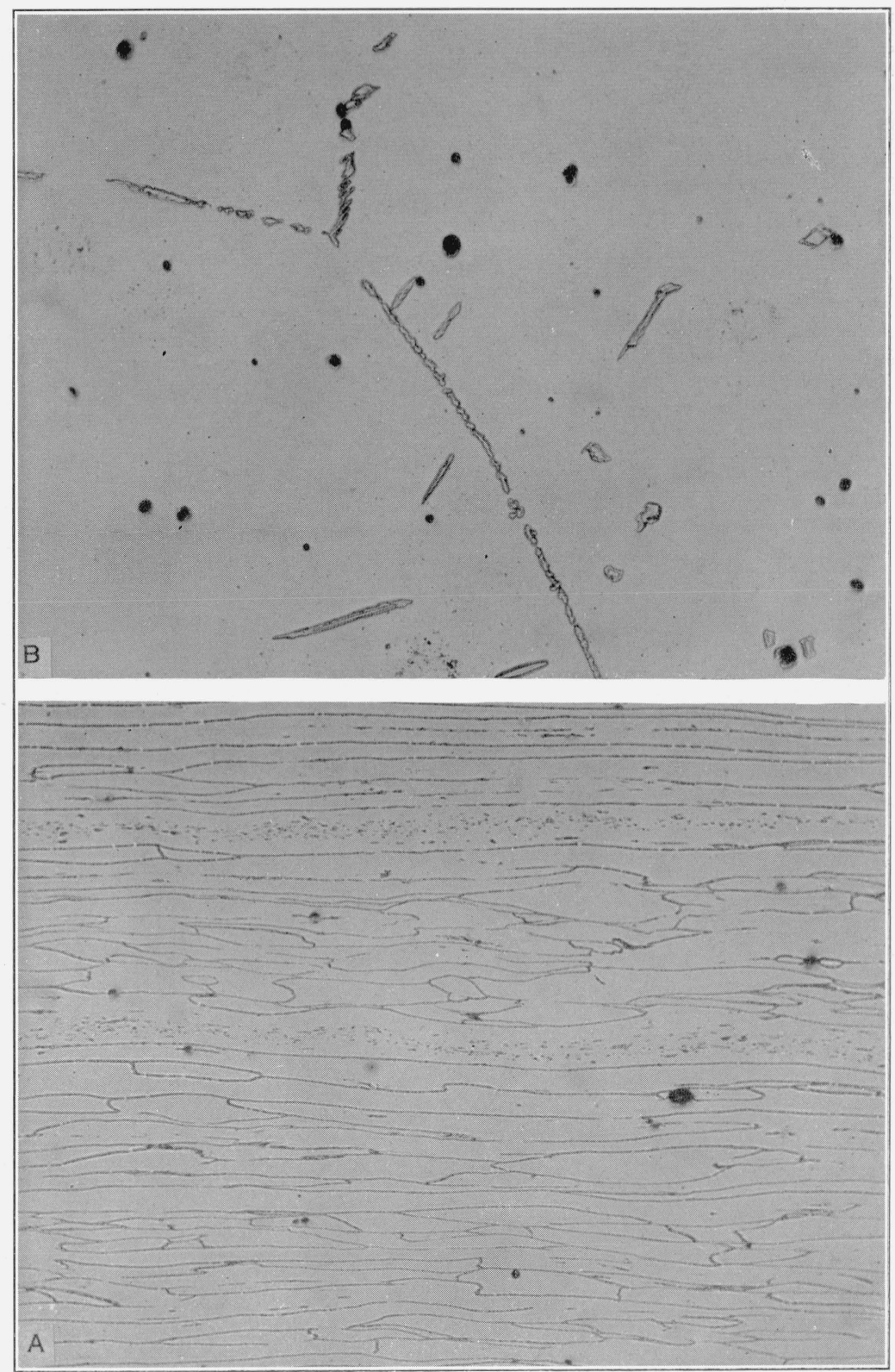

FIgure 5.-Microstructure of iron-chromium-aluminum-cobalt alloy (iron 69.0, chromium 23.4, aluminum 5.7, cobalt 1.9, carbon 0.06 percent); $\times 100$.

A. Sample 1580 (cold-rolled), before heat treatments. B. Sample 1580 , after heat treatments to various temperatures up to $1,400^{\circ} \mathrm{C}$. 


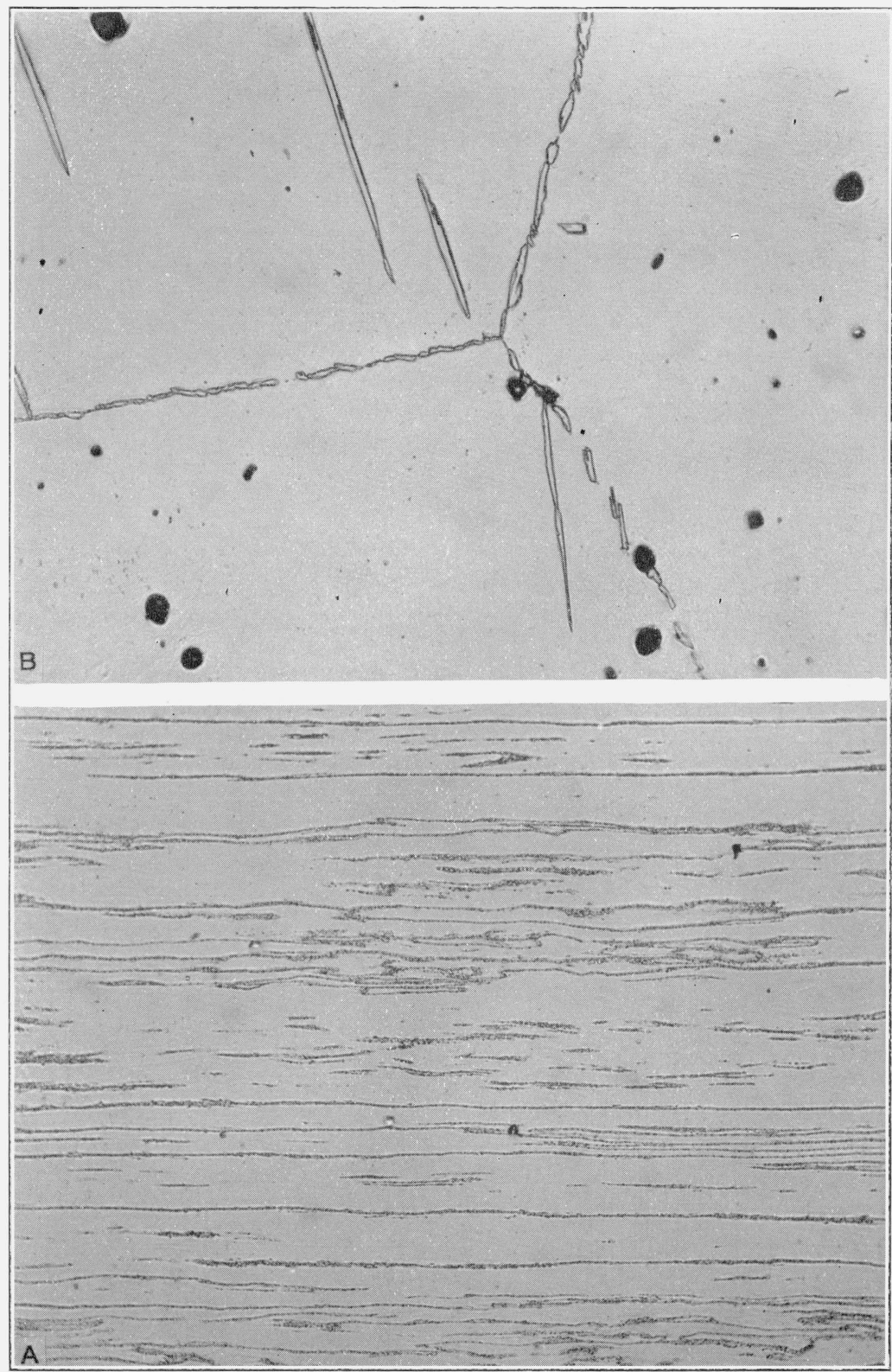

Figure 6.-Microstructure of iron-chromium-aluminum-cobalt alloy (iron y0.9. chromium 22.6, aluminum 4.5, cobalt 2.0, carbon 0.09 percent); $\times 100$.

A. Sample 1581 (hot-rolled), before heat treatments. B. Sample 1581, after heat treatments to various temperatures up to $1,400^{\circ} \mathrm{C}$. 


\section{STRUCTURE}

Longitudinal sections were cut from the samples of heat-resisting alloys before the expansion tests and after the heat treatments for the determinations of growth. These sections were prepared for metallographic examination. The sections were etched electrolytically in cold concentrated nitric acid.

Figure 3 shows the structure of iron-chromium-aluminum alloy (sample 1586). Before heat treatments, the hot-rolled alloy consisted of a fairly homogeneous structure of equiaxed crystals with little or no precipitation of intermetallic compounds. After heat treatments to various temperatures up to $1,400^{\circ} \mathrm{C}$, excessive grain growth was evident. There still remained in the huge grains the solid solution phase, but with disjointed traces of compounds along the grain boundaries.

Figures 4 to 6 show the structures of iron-chromium-aluminumcobalt alloys (samples 1579 to 1581). Intermetallic compounds along grain boundaries are exhibited in the micrographs of these alloys before the heat treatments. The constituents were broken up into a series of fine beads in each case, doubtless as a result of severe mechanical working. The effects of this are seen particularly in figures 5 and 6 .

The micrographs of the samples of iron-chromium-aluminumcobalt alloys after heat treatments to various temperatures up to $1,400^{\circ} \mathrm{C}$ indicate that excessive grain growth occurred. The structures of these alloys after the heat treatments were virtually identical. The micrographs indicate huge grains of a solid solution with abundant precipitation of intermetallic compounds in the grain boundaries and random distribution in small amounts of the same constituent in the form of needles within the grains.

The chief microstructural effect observed as a result of heat treatments on the heat-resisting alloys is in each case a tremendous grain growth.

\section{DISCUSSION}

Figure 7 gives a comparison of the expansion curves of heat-treated or hot-rolled heat-resisting alloys, Chromel $\mathrm{A}^{8}$ and Nichrome IV. ${ }^{8}$ Sample 1292 (chromel A) indicates the greatest linear expansion between 20 and $1,000^{\circ} \mathrm{C}$, and sample 1581 (iron-chromium-aluminumcobalt alloy containing the lowest content of aluminum in this group of alloys) indicates the smallest linear expansion. An examination of the thermal-expansion curves in figures 1,2, and 7, indicates that there is no polymorphic transition in these alloys between 20 and $1,000^{\circ} \mathrm{C}$. Öhman [9] stated that Kanthal alloy is ferritic at all temperatures and consequently undergoes no transformation at any temperature.

Referring to the grinding of iron-chromium-aluminum alloy, ${ }^{9}$ Hoyt and Scheil [5] stated that this alloy has a low thermal conductivity and a relatively large coefficient of expansion, as a consequence of which relatively large temperature differences must be set up when the metal is ground on the ordinary wheel. On this account the alloy is not ground except under exceptional circumstances or unless the material has been worked to a fine size.

Hoyt [8] stated that in the design and construction of furnaces for operation at the high temperatures which can be attained with the

\footnotetext{
${ }^{8}$ Data obtained from publication by Hidnert [1].
}

- Smith Alloy No. 10. 


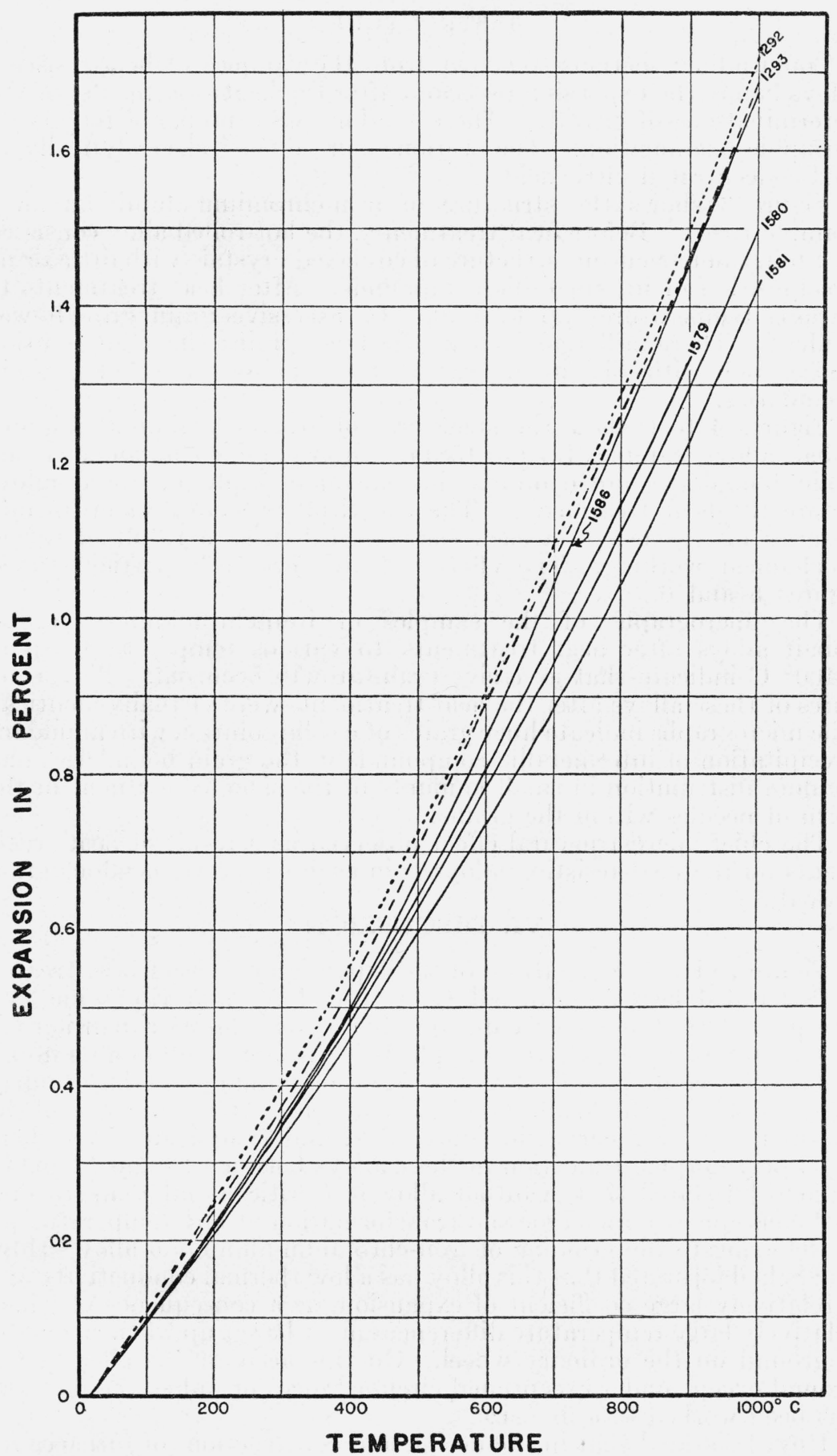

FIGURE 7.-Comparison of linear expansion of heat-resisting alloys.

Sample 1586. Iron-chromium-aluminum alloy.

Samples 1579 to 1581 . Iron-chromium-aluminum-cobalt alloys.

Sample 1292A. Chromel A.

Sample 1293. Nichrome IV 
iron-chromium-aluminum alloy heating element, due regard must be paid to the necessity for providing the right kind of refractories, and for using suitable supports which allow for the thermal expansion, growth, and sagging of the resistance element.

Nordstroem [9] reported that the tensile strength of iron-chromiumaluminum-cobalt alloys falls off sharply on heating. He stated that it is therefore necessary to provide proper support for heating elements made of these alloys. "Corrugated elements hanging from knobs on the sides of the furnace are not suitable above $2,000^{\circ} \mathrm{F}$, as the element can elongate by its own weight. The most satisfactory construction is when the element is laid in troughs or shelves formed by protruding ends of header brick."

Ray [10] reported that he had some experience with Kanthal A1 heating-element wire in work which he did with an automatic dentalinlay melting and casting machine. He used about 14 feet of No. 20 or No. 21 gage wire wrapped in small grooves on a cylindrical muffle made of soapstone. Alundum cement and silica firebrick high in free silica were placed in close contact with the wire (in violation of the manufacturer's instructions) to serve as insulation. The muffle was connected so that electric current heated it to about $1,000^{\circ} \mathrm{C}$ in 3 minutes and then the current was automatically shut off. The muffle was allowed to cool to $300^{\circ} \mathrm{C}$, which required about 18 minutes. Intermittent heating and cooling were continued for about 150 hours, after which it was found that the wire had expanded so much that it not only cracked the muffle but also broke the alundum refractory and pushed the porous silica firebrick away. The automatic device which turned on and shut off the current, operated by time and not by temperature. A recording pyrometer indicated that the temperature of the inside of the muffle near the center varied between 1,000 and $1,150^{\circ} \mathrm{C}$. The temperature of the heating-element wire was somewhat hotter than this temperature. After 150 hours of operation, which corresponded to more than 400 cycles of heating and cooling, the wire, especially that part near the center, had grown so much that the coils were grouped together. Ray also observed that the resistance of the wire had increased appreciably and consequently a longer time was required to bring the muffle up to $1,150^{\circ} \mathrm{C}$ at the end of 150 hours than was required at the beginning.

The densities of mechanically worked alloys of iron-chromiumaluminum and iron-chromium-aluminum-cobalt increased 1.12 to 2.50 percent after heat treatments to $1,400^{\circ} \mathrm{C}$. Kahlbaum and Sturm [11], Goerens [12], and Johnston and Adams [13] reported smaller increases in density after annealing cold-drawn wires of some metals and alloys. For example, the increase in density for iron after annealing at $1,040^{\circ}$ $\mathrm{C}$, was 0.26 percent. The reader is referred to Tammann [14] for a discussion of volume and density changes of metals and alloys.

The samples of heat-resisting alloys indicated excessive growth, excessive density changes, and excessive grain growth as a result of heat treatments at elevated temperatures.

\section{CONCLUSIONS}

1. A comparison of the average coefficients of expansion of the two groups of heat-resisting alloys which were investigated, is given in table 7. Coefficients of expansion of Chromel $\mathrm{A}$ and Nichrome IV are included in this table. 
TABLE 7.-Comparison of average coefficients of expansion of heat-resisting alloys

\begin{tabular}{|c|c|c|c|c|c|c|c|c|c|c|c|c|c|c|c|}
\hline \multirow[b]{2}{*}{ Alloys } & \multicolumn{5}{|c|}{ Chemical composition } & \multicolumn{10}{|c|}{ Average coefficients of expansion per degree centigrade } \\
\hline & $\mathrm{Fe}$ & $\mathrm{Cr}$ & $\mathrm{Al}$ & Co & $\mathrm{Ni}$ & $\begin{array}{l}20 \text { to } \\
100^{\circ} \mathrm{C} .\end{array}$ & $\begin{array}{c}20 \text { to } \\
200^{\circ} \mathrm{C}\end{array}$ & $\begin{array}{c}20 \text { to } \\
300^{\circ} \mathrm{C} \text {. }\end{array}$ & $\begin{array}{l}20 \text { to } \\
400^{\circ} \mathrm{C}\end{array}$ & $\begin{array}{l}20 \text { to } \\
500^{\circ} \mathrm{C} .\end{array}$ & $\begin{array}{l}20 \text { to } \\
600^{\circ} \mathrm{C} \text {. }\end{array}$ & $\begin{array}{l}20 \text { to } \\
700^{\circ} \mathrm{C} .\end{array}$ & $\begin{array}{l}20 \text { to } \\
800^{\circ} \mathrm{C}\end{array}$ & $\begin{array}{l}20 \text { to } \\
900^{\circ} \mathrm{C}\end{array}$ & $\begin{array}{c}20 \text { to } \\
1,000^{\circ} \mathrm{C} .\end{array}$ \\
\hline Iron-chromium-aluminum...-- & $\begin{array}{l}\% \\
53.1\end{array}$ & $\begin{array}{l}\% \\
38.6\end{array}$ & $\begin{array}{l}\% \\
7.9\end{array}$ & $\%$ & $\%$ & $\left\{\begin{array}{l}\times 10^{-6} \\
11.4 \text { to } \\
12.0\end{array}\right.$ & $\begin{array}{l}\times 10^{-6} \\
11.9 \text { to } \\
12.2\end{array}$ & $\begin{array}{l}\times 10^{-6} \\
12.4 \text { to } \\
12.7\end{array}$ & $\begin{array}{l}\times 10^{-6} \\
12.7 \text { to } \\
13.1\end{array}$ & $\begin{array}{l}\times 10^{-6} \\
13.2 \text { to } \\
13.9\end{array}$ & $\begin{array}{l}\times 10^{-6} \\
14.0 \text { to } \\
14.6\end{array}$ & $\begin{array}{l}\times 10^{-6} \\
14.6 \text { to } \\
15.4\end{array}$ & $\begin{array}{l}\times 10^{-6} \\
15.0 \text { to } \\
15.9\end{array}$ & $\begin{array}{l}\times 10^{-6} \\
15.5 \text { to } \\
16.5\end{array}$ & $\begin{array}{r}\times 10^{-6} \\
16.0 \text { to } \\
17.1\end{array}$ \\
\hline 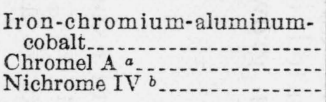 & $\left\{\begin{array}{r}68.5 \text { to } \\
70.9 \\
0.65 \\
.40\end{array} \mid\right.$ & $\begin{array}{r}22.6 \text { to } \\
23.4 \\
19.3 \\
20.4\end{array}$ & $\begin{array}{r}4.5 \text { to } \\
6.2 \\
\hdashline-1 \\
\hdashline-9-\end{array}$ & $\begin{array}{r}1.9 \text { to } \\
2.0 \\
-\end{array}$ & \begin{tabular}{r}
$\mid$ \\
\hdashline 77.0 \\
76.80
\end{tabular} & $\begin{array}{r}11.4 \text { to } \\
11.7 \\
13.6 \\
13.0\end{array}$ & $\begin{array}{r}12.2 \\
12.6 \text { to } \\
14.0 \\
13.3\end{array}$ & $\begin{array}{r}11.9 \text { to } \\
12.4 \\
14.3 \\
13.3\end{array}$ & $\begin{array}{r}12.1 \text { to } \\
12.9 \\
14.5 \\
13.9\end{array}$ & $\begin{array}{r}12.4 \text { to } \\
13.4 \\
15.1 \\
14.7\end{array}$ & $\begin{array}{r}12.7 \text { to } \\
13.9 \\
15.6 \\
15.3\end{array}$ & $\begin{array}{r}10.4 \\
13.0 \text { to } \\
14.4 \\
16.1 \\
15.8\end{array}$ & $\begin{array}{r}13.4 \text { to } \\
14.7 \\
15.5 \\
16.2\end{array}$ & $\begin{array}{r}13.9 \text { to } \\
15.1 \\
17.0 \\
16.7\end{array}$ & $\begin{array}{r}14.5 \text { to } \\
15.8 \\
17.6 \\
17.2\end{array}$ \\
\hline
\end{tabular}

a Manganese 2.50 percent.

${ }^{b}$ Manganese 1.92 percent. 
2. The average coefficients of expansion of a heat-treated ironchromium-aluminum alloy containing approximately 53 percent of iron, 39 percent of chromium, and 8 percent of aluminum are slightly greater than the coefficients of a hot-rolled alloy.

3. The substitution of approximately 39 percent of chromium for the same amount of iron in an iron-aluminum alloy containing about 8 percent of aluminum, has little effect on the coefficients of expansion for temperature ranges between 20 and $500^{\circ} \mathrm{C}$.

4. The substitution of 4.5 to 6.2 percent of aluminum and about 2 percent of cobalt for an equivalent amount of iron in an ironchromium alloy containing about 23 percent of chromium, increases the coefficients of expansion.

5. No polymorphic transition was observed in the heat-resisting alloys between 20 and $1,000^{\circ} \mathrm{C}$.

6 . The heat-resisting alloys indicated growth after various heat treatments at temperatures up to $1,400^{\circ} \mathrm{C}$. The growth of the ironchromium-aluminum-cobalt alloys ranged from 1.21 to 2.81 percent. The growth of the iron-chromium-aluminum alloy was nearly 1 percent. The growth decreased with an increase in the aluminum content. Additional heat treatments on these alloys would probably cause additional growth.

7. The densities of the mechanically worked iron-chromium-aluminum alloy and iron-chromium-aluminum-cobalt alloys increased 1.12 to 2.50 percent as a result of various heat treatments at temperatures up to $1,400^{\circ} \mathrm{C}$. The cross-sectional areas of the alloys presumably decreased, for both the densities and the lengths increased.

8. Tremendous grain growth occurred in the iron-chromium-aluminum alloy and iren-chromium-aluminum-cobalt alloys as a result of various heat treatments to elevated temperatures.

The author thanks the following members of the staff of the National Bureau of Standards for the assistance mentioned: J. L. Hague and W. H. Jukkola for the chemical analyses of the heatresisting alloys; S. Alpher and N. Green for the density determinations; H. O. Willier for the metallographic examination; and J. Burks for his assistance during a part of this investigation.

\section{REFERENCES}

[1] P. Hidnert, Thermal expansion of heat-resisting alloys: Nickel-chromium, ironchromium, and nickel-chromium-iron alloys, BS J. Research 7, 1031 (1931) RP388.

[2] S. L. Hoyt and R. S. Archer, U. S. Patent 1,995,923 (March 26, 1935) assigned to A. O. Smith Corporation, Milwaukee, Wis.

[3] H. G. A. v. Kantzow, U. S. Patent 1,717,284 (June 11, 1929).

[4] W. Souder and P. Hidnert, Measurements on the thermal expansion of fused silica, BS Sci. Pap. \%1, 1 (1926) S524.

[5] S. L. Hoyt and M. A. Scheil, A new heat-resistant alloy, Trans. Am. Soc. Metals \$3, 1022 (1935).

[6] A. Schulze, Über die thermische Ausdehnung von Eisenlegierungen, Z. tech. Physik 9, 338 (1928).

[7] E. Öhman, High-temperature resistor uses iron-base alloy, Metal Progress 20, 78 (Dec. 1931).

[8] S. L. Hoyt, A new resistor alloy-chromium-aluminum-iron, Metal Progress 28, 38 (July 1935). 
[9] G. Nordstroem, Alloys good at temperatures above 2,100 ${ }^{\circ} \mathrm{F}$., Metal Progress 28, 68 (Oct. 1935).

[10] Private communication dated May 10, 1937 from K. W. Ray, Director of Research, General Refineries, Inc., Minneapolis, Minn.

[11] G. W. A. Kahlbaum and E. Sturm, Über die Veränderlichkeit des spezifischen Gewichtes, Z. anorg. Chem. 46, 217 (1905).

[12] P. Goerens, Über den Einfluss der Wärmebehandlung auf die Eigenschaften von kalt bearbeitetem Flusseisen, Ferrum 10, 226 (1912).

[13] J. Johnston and L. H. Adams, Die Dichte fester Stoffe, mit besonderer Berücksichtigung der durch hohe Drucke hervorgerufenen dauernden Änderungen, Z. anorg. Chem. 76, 274 (1912).

[14] G. Tammann, Lehrbuch der Metallkunde, vierte erweiterte Auflage, 1932 (Verlag von Leopold Voss, Leipzig).

Washington, November 30, 1937. 